\title{
Mопнуиародиый BEPTLIUT BETEPLIAPUM
}

Редакционный совет

А.А. Стекольников - гл. ред., академик РАН,Д.в.Н., проф., СПб.

Л.Ю.Карпенко-зам.гл.ред,, д.б.н., проф.,СПб.

А.И. Ятусевич - зам. гл. ред. Д.в.н. проф.,академик РАН, Витебск.

Редакционная коллегия

А.А. Алиев-д.в.н., проф., СПб.

Н.Л. Андреева-д.б.н., проф., СПб.

Л.М. Белова-д.б.н., проф., СПб.

М.И. Гулюкин- акад. РАН, д.в.н., проф.,Москва.

Н.В. Зеленевский- д.в.н., проф., СПб.

С.П. Ковалев- д.в.н., проф., СПб.

А.А. Кудряшов- д.в.н., проф., СПб.

В.А. Кузьмин-д.в.н., проф., СПб.

М.Н. Макарова- д.мед.н., проф., СПб.

К.В. Племяшов- член.-корр. РАН, д.в.н.,проф., СПб.

Б.С. Семенов-д.в.н., проф., СПб.

А.М. Смирнов- акад. РАН, д.в.н., проф., Москва.

В.В. Сочнев - член.-корр. РАН, д.в.Н., проф., Н.Новгород.

А.А. Сухинин-д.б.н., проф., СПб.

А.Н. Шиков- д.фарм.н., проф., СПб.

Mustafa Atasever- Prof., Dr. Erzurum,Turkiye.

Ю.К. Ковалёнок-д.в.Н., проф., Витебск, Республика Беларусь.

Kushvar Galib Mammadova-Dr., Azerbaijan.

Н.Б. Сарсембаева-д.в.н., проф., Алматы,Республика Казахстан.

Ilia Tsachev- DVM, MSc, PhD, DSc Prof., Stara Zagora, Bulgaria.

О.Ю. Беспятых- д.б.н., доцент, Киров.

В. А. Илюха - д.б.н., доцент, Петрозаводск.

И.А. Плотников- д.б.н., профессор, Киров

С.В. Бекетов-д.б.н., в. н. с., Самара.

В.Н. Воронин - д.б.Н., профессор, СПб.

А.Н. Квочко- д.б.н., профессор, Ставрополь.

В.Г. Скопичев- д.б.н., профессор, СПб.

А.О. Фролов- д.б.н., г.н.с., Санкт-Петербург

О.И. Станишевская - д.б.н., профессор, СПб.

А.Е. Болгов - д.с.-х. н., профессор, Петрозаводск.

А. А. Лукин - д.б.н., профессор, СПб.

И.Ш. Шапиев - д.с.-х. н., профессор, СПб.

Н. В. Пристач - д.с.-х. н., профессор, СПб.

В. Б.Галецкий - д.с.-х. н., СПб.

Л.В. Романенко - д.с.-х. н., член РАЕ, СПб

Максимов В.И.- д.б.н., профессор, Москва

Редакционно-технический отдел

Н.Л. Андреева- д.б.н., проф., СПб.

Л.А. Лукоянова- к.в.н., СПб.

О.С. Попова- к.в.н., СПб.

В.В. Крюкова- к.в.н., СПб ( анг.яз)

Сдано в набор 10.06.2020

Подписано к печати 19.06.2020

Формат 70×100 1/16.

Бумага глянцевая № 1. Печать офсетная.

Усл. печ. л. 13,25+0,25 цв. вкл.

Усл. Кр.-отт. 18,2. Тираж 1001 экз.
Editorial council

A. A. Stekolnikov - editor in chief, academic of RAS, doctor of veterinary sciences, professor, St. Petersburg

L.Y. Karpenko - deputy editor, doctor of biology sciences, professor,St. Petersburg.

A. I. Yatusevich - deputy chief editor, doctor of veterinary sciences, professor, academic of RAS, Vitebsk.

Editorial board

A. A. Aliev, doctor of veterinary sciences, doctor of economics, prof., St. Petersburg

N. L. Andreeva- doctor of veterinary sciences, professor, St. Petersburg

L. M. Belova- doctor of biology sciences, professor, St. Petersburg

M. I. Gulyukin- academic of RAS, doctor of veterinary sciences, prof., Moscow

N. In. Zelenevskiy - doctor of veterinary medicine, doctor of economics,

N. In. Zelenevskiy
prof, St. Petersburg.

S. P. Kovalev - doctor of veterinary sciences, prof., St. Petersburg.

A. A. Kudryashov -doctor of veterinary sciences, professor, St. Petersburg V. A. Kuzmin- doctor of veterinary sciences, professor, St. Petersburg.

M. N. Makarova - doctor of medicine, professor, St. Petersburg.

K. V. Plemyashov - corr. member of RAS, doctor of veterinary sciences, prof., St. Petersburg

B. S. Semenov - doctor of veterinary sciences, professor, St. Petersburg

A. M. Smirnov- academic of RAS, doctor of veterinary sciences, prof.,

Moscow

V. V. Sochnev- corr. member of RAS, doctor of vet. sciences, prof., N. Novgorod.

A. A. Sukhinin - doctor of biology sciences., prof, St. Petersburg

A. N. Shikov- doctor of pharmacology sciences, prof., St. Petersburg

Mustafa Atasever- professor., Dr. Erzurum, Turkey

Y. K. Kovalenok - doctor of veterinary sciences, prof., Vitebsk

Kushva Galiba Mammadova - doctor, Azerbaijan

N. B. Sarsembayeva -doctor of vet. sciences, prof., Almaty, Republic of Kazakhstan

Ilya Sachev - DVM, MSc, PhD, DSc, Prof., Stara Zagora, Bulgaria

O. Yu. Bespyatykh-doctor of biology sciences, associate professor, Kirov

V. Yu. Ilyuha - doctor of biology sciences, associate professor, Petrozavodsk

V. A. Ilyuha- doctor of biology sciences, associate professor,
I. A. Plotnikov- doctor of biology sciences, professor, Kirov

S. V. Beketov-doctor of biology sciences, Samara

V. N. Voronin- doctor of biology sciences, professor, Saint Petersburg

A. N. Kvochko - doctor of biology sciences, professor, Stavropol

V. G. Skopichev-doctor of biology sciences, professor, Saint- Petersburg

A. O. Frolov- doctor of biology sciences, senior science member, SaintPetersburg

O. I. Stanishevskaya - doctor of biology sciences, professor, SaintPetersburg

A. E. Bolgov-doctor of agricultural sciences, professor, Petrozavodsk

A. E. Bolgov-doctor of agricultural sciences, professor, Petrozavodsk
A. A. Lukin - doctor of biology sciences, professor, Saint-Petersburg I. S. Shapiev - doctor of agricultural sciences, professor, St. Petersburg N. V. Pristach-doctor of agricultural sciences, professor, St. Petersburg V. B. Galetsky- doctor of agricultural sciences, St. Petersburg.

L. V. Romanenko-doctor of agricultural sciences, member of RAE St. Petersburg

Maximov V.I. -doctor of biology sciences, professor, Moscow

Editorial and technical Department

N. L. Andreeva - doctor of biology sciences, prof, St. Petersburg

L. A. Lukoyanova - PhD of Vet.Med., St. Petersburg

O. S. Popova - PhD of Vet Med., St. Petersburg

V.V. Kriukova - PhD of Vet Med., St. Petersburg (English)

Sent to 10.06 .2020

Signed for printing 19.06.2020

The format of $100 \times 701 / 16$

Glossy paper number 1 . Offset printing

Conv. Pec. liter. $13.25+0,25 \mathrm{fl}$. incl.

Conv. Cr. - ott . 18.2 . Circulation 1001 copies.

На 1 странице обложки: Здание Кабардино-Балкарского государственного аграрного университета имени В. М. Кокова - один из крупнейших сельскохозяйственных вузов Северного Кавказа. 
Международный вестник ветеринарии, № 2, 2020 己.

\section{НАУЧНО-ПРОИЗВОДСТВЕННЫЙ}

\section{ЖУРНАЛ}

Номер госрегистрации СМИ ПИ № ФС 77-28268 от 18 мая 2007 г. Подписной индекс в агентстве Роспечать 82393.

Учредитель — Федеральное государственное образовательное учреждение высшего образования «СанктПетербургский государственный университет ветеринарной медицины» (ФГОУ ВО «СПбГУВМ»)

Журнал основан в январе 2004 года в Санкт-Петербурге и входит в список ведущих лицензируемых научных журналов, в которых должны быть опубликованы основные научные результаты диссертаций на соискание ученой степени доктора и кандидата наук.

Журнал распространяется по всем регионам России и Республике Беларусь (ВУЗЫ, НИИ, ВЕТЕРИНАРНЫЕ ОТДЕЛЫ).

Журнал выходит не менее 4 раз в год. В нем публикуются работы по всем основным вопросам ветеринарии и смежным дисциплинам.

В этот журнал Вы можете поместить рекламу Вашей фирмы. Объявления и коммерческая реклама публикуются после оплаты. Срок исполнения - в течение 3 месяцев.

Редакция не несет ответственности за содержание рекламных объявлений.

При перепечатке ссылка на журнал обязательна.

Мнение авторов и редакции по отдельным вопросам может не совпадать.

Плата с аспирантов за публикацию рукописи не взимается.

Справки и технические возможности типографии, в которой печатается журнал, оговариваются по телефону (812) 387-1158.

Адрес редакции: 196084, СПб, ул. Черниговская дом 5, СПбГУВМ, редакция журнала «Международный вестник ветеринарии» (МBB).

\section{RESEARCH AND PRODUCTION JOURNAL}

State registration number media PI № FS 77-28268 on May 18, 2007. Subscription Index Rospechat 82393.

Founded in January 2004 by Federal State Educational Institution of Higher Education "St. Petersburg State University of Veterinary Medicine" ( FSEIHPE " SPbGUVM")

International Bulletin of Veterinary an academic international peer-reviewed journal that publishes original research articles as well as review articles in veterinary sciences and related academic disciplines. It covers all the scientific and technological aspects of veterinary sciences in general, anatomy, physiology, biochemistry, pharmacology, microbiology, pathology, public health, parasitology, infectious diseases, clinical sciences, alternative veterinary medicine and other biomedical fields.

The manuscripts submitted to this journal must be previously unpublished and not be under consideration for publication elsewhere. Manuscripts that are found to have been plagiarized from a manuscript by other authors, whether published or unpublished, will incur plagiarism sanctions.

This journal, including all individual contributions and illustrations published therein, is legally protected by copyright. Any use, exploitation or commercialisation is illegal and liable to criminal prosecution.

Requests about legal photocopy reproduction, copyright or duplication processing should be addressed to the editorial office:

196084, St. Petersburg, ul . Chernihiv house 5 SPbGUVM, Editorial Board of "International Bulletin of Veterinary Medicine" (IBVM), phone +7-812- 3871158. 
Международный вестник ветеринарии, № 2, 2020 2.

\section{СОДЕРЖАНИЕ}

Инфекционные болезни

Инвазионные болезни

Фармакология токсикология, фармация
- Выделение стрептококков из проб патологического материала при факторных инфекииях крупного рогатого скота в хозяйствах Кабардино-Балкарской Республики. Жемухов А.Х., Мешев Э. М.

- Эпизоотическая ситуация по артриту-энцефалиту коз (caev) в иентрально-восточной зоне Новосибирской области. И.Н. Пенькова, Н.Ю. Бальббина, В.Ю. Коптев, Н.А. Шкиль

- Особенности распространения хламидийной инфекиии в городе Москва. Струговщиков А.Ю., Пудовкин Н.А., Салаутин В.В.

- Антимикробная активность препарата Фумийод в отношении изолятов условно-патогенной микрофлоры от животных с признаками респираторных болезней. Кузьмин В.А., Фогель Л.С., Сухинин А.А., Макавчик С.А., Смирнова Л.И., Орехов Д.А.

- Ассочиативная желудочно-китечная инвазия лотадей в Ленинградской области. Н.А. Гаврилова, Л.М. Белова, О.А., Логинова, Р.С. Ситникова

- Эпизоотическая ситуачия по гельминтозам лошадей в частных хозяйствах Ленинградской области. Н. А. Гаврилова, Л. М. Белова, О. А. Логинова, М.Г. Роберман, Р. С. Ситникова

- Распространение эхинококкоза среди крупного рогатого скота и овеи в республике Таджсикистан. Шодмонов И., Енгашев С.В.

- Практическая иченность пищевой приманки Флайблок® грануль для снижения численности зоофильных мух в условиях свиноферм. Енгашев С.В., Василевич Ф.И., Новак М.Д., Енгашева Е.С.

- Выделение антимикробных пептидов из личинок hermetia illucеns и перспектива их использования. Смирнова К. Ю., Крылова Л. С., Ремизов Е. К., Горшунова С. В.

- Количественный анализ, инвазированности безнадзорных собак эхинококкозом (в зависимости от возраста и времени года) в Кабардино-Балкарии. Биттиров А. М., Кабардиев С. Ш.

- Фауна био - и геогельминтов класса cestoda и петаtoda у волка (canis lupиs) в Кабардино-Балкарии. Кабардиев С.Ш., Биттиров А. $M$.

- Клинический случай обнаружения eimeria brunetti y изыплятбройлеров в Красноярском крае. О.А. Фролова, В.Н. Афонюшкин, Н.В. Донкова

- Роль токсикозов в приспособлении экосистем к антропогенному загрязнению среды (на примере токсикозов водных животных). Макрушин А.В. Васильев А.С.; Аршаница Н.М., Ляшенко О.А., Стекольников А.А., Гребияов М.Р.

- Монизен ${ }^{\circledR}$ форте при паразитарных болезнях овеи. Енгашева E. С., Колесников В. И.

- Применение композиции биостимуляторов для увеличения количественных и качественных показателей инкубации. И.С. Луговая 
Международный вестник ветеринарии, № 2, 2020 己.

- Диналика белковых фракций сылоротки крови лотиадей при дегельминтизации препаратом из группь макрочиклических лактонов на фоне применения пробиотика. Муллагалиева О.А, Закрепина Е.Н., Воеводина Ю.А

- Антиликробная активность энрофлоксачина in vitro. Д.В. Юрин, В.В. Невзорова, А.А. Балбуиякая, С.С. Белимова

- Терапия экспериментального сальмонеллёза цьыплят антимикробными препаратами группь фоторхинолонов. В.Н. Сквориов, Д.В. Юрин, В.В. Невзорова, А.Д. Мазур

- Новое дезинфицирующее средство «БА - 12» для обеззараживания почвенных очагов сибирской язвы. Султанов А.А., Сущиих В.Ю., Канатов Б., Нурлан К.

- Влияние препарата "Гепатон" на реакиии перекисного окисления липидов. Понамарев В.С, Попова О.С.

- Влияние препарата с гепатопротекторной активностью «Гепатон» на показатели периферической крови лабораторных животных. Понамарев В.C.

- Использование сорбентов в рыбоводстве. Барышев В.А., Ташбаев Д.У., Попова O.C.

Зоогигиена, санитария, кормление

Биохимия, анатомия, физиология
- Применение метода поs для оиенки симбиотической микрофлоры рубиа северных оленей российской Арктики. Ильина Л.А., Филиппова В.А., Йылдырым Е.А., Дубровин А.В., Дунямев Т.П., Соболев Д.В., Лайшев К.A.

- Мониторинг афлатоксина в1 в кормах республики Татарстан. Танасева С.А., Ермолаева О.К., Матросова Л.Е., Семенов Э.И.

- Зоогигиеническая оченка качества молока коз различных пород. Ткачев A.B.

- Роль углеводно-витаминно-минерального концентрата в кормлении коз. Хайруллин Д.Д., Шакиров Ш.К., Антонов М.В.

- Изучение признаков молочной продуктивности у коров айриирской породы племенного хозяйства Ленинградской области. Мукий Ю.В.

- Влияние технологического стресса на иммунологическую реактивность поросят. Крячко О.В., Будник А.О.

- Анализ влияния меди на углеводный обмен у карпа. Карпенко Л.Ю., Полистовская П.А., Енукашвили А.И., Бальикина А.Б.

- Анатомо-топографические особенности костей пояса тазовой конечности овец породы дорпер. Мамедкулиев А.К., Щипакин М.В.

162

165

- Архитектоника артериального русла многокамерного желудка овеи эдильбаевской породы в возрастном аспекте. Мельников С.И., Щипакин М.В.

- Особенности морфологии почек у индейки широкогрудой и утки пекинской. Первенеикая М. В, Фоменко Л.В.

- Динамика показателей неспециифической защиты организма голитинизированных черно-пестрых пород коров в зависимости от месяиа стельности. Карпенко Л.Ю., Погодаева А.А., Бахта А.А.

\section{3}


Международный вестник ветеринарии, № 2, 2020 г.

- Патологоанатомические изменения при энтеропатиях вызванными дифиллоботриозом у собак. Каменов К.С., Шинкаренко А.Н.,

- Динамика клеточнылх факторов иммунной системы здоровых норок, больных эймериидозами и на фоне специфической и иммунокорректируюшей терапии. Кузнеиов Ю.Е., Кузнецова Н.В.

- Клинические испытания препарата Тилдок при микоплазмозе свиней. Токарева О.А., Токарев А.Н., Енгашев С.В., Енгашева Е.С., Мусин А.Р., Васильева Н.C.

Акушерство, гине-• Мероприятия, направленные на профилактику заболевания коров макология ститами. Батраков А.Я., Племямов К.В, Виденин В.Н., Яиин А.В.

- Поиск и разработка способа терапии при послеродовых эндометритах у коров. Перерядкина С.П., Болдарев А.А., Колесников П.В., Гальченко В.A.

- Стимуляция воспроизводительной функиии у коров-первотелок. Гамаюнов В.М.-к.б., Кольцуов Д.Н., Онуфриев В.А., Целуева Н.И.

По заявкам ветспециалистов, граждан, юридических лиц проводим консультации, семинары по организационно-правовым вопросам, касающихся содержательного и текстуального анализа нормативных правовых актов по ветеринарии, практики их использования в отношении планирования, организации, проведения, ветеринарных мероприятиях при заразных и незаразных болезнях животных и птиц.

Консультации и семинары могут быть проведены на базе Санкт-Петербургского университета ветеринарной медицины или с выездом специалистов в любой субъект России.

Тел/факс (812) 365-69-35,

Моб. тел.: 8(911) 176-81-53, 8(911) 913-85-49, e-mail: 3656935@gmail.com 
Международный вестник ветеринарии, № 2, 2020 己.

\section{CONTENTS}

Infectious diseases

Invasive disease

Pharmacology, toxicology, pharmacy
- Isolation of Streptococcus spp., from the probes of pathological material of factor infections of cattles in the Kabardino-Balkarian Republic. ZhemuhovA. H., Meshev E.M.

- Epizootic situation on goat arthritis-encephalitis (caev) in the central-eastern zone of the Novosibirsk region. I.N. Penkova, N.Yu. Balibina, V.Yu.Koptev, N.A. Shkill.

- Features of the spread of chlamydia infection in Moscow. Strugovschikov A. Yu., Pudovkin N. A., Salautin V. V.

- Antimicrobial activity of the drug Fumiod in respect to isolates of conditionally pathogenic microflora from animals with signs of respiratory diseases. V.A. Kuzmin, L.S. Vogel, A.A. Sukhinin, S.A. Makavchik L.I.Smirnova, D.A. Orekhov

- Associative gastrointestinal infection of horses in Leningrad region. Gavrilova N. A, Belova L. M., Loginova O. A., Sitnikova R. S.

- Episootic situation on helminthiasis of horses in private farms of the Leningrad region. Gavrilova N. A., Belova L. M., Loginova O. A., Roberman M.G., Sitnikova R. S.

- Epizootic process of echinococcosis at sheep and cattle in Tajikistan regione. Engashev S.V., Shodmonov I.

- Practical value of food bait «Fliblok granules» in order to reduce the number of zoophilic flies at the pig farms. Engashev S.V., Vasilevich F. I., , Novak M.D., , Engasheva E.S.

- Isolation of antimicrobial peptides from larvae of Hermetia illucens and the prospect of their applying. Smirnova K. Yu., Krylova L.S., Remizov E.Ki., Gorshunova S. Vl.

- Quantitative analysis of the invasion of the street dogs by echinococcosis (depending on age and time of year) in Kabardino-Balkaria. Bittirova A. M., Kabardiev $S$.

- Fauna of bio- and geohelmintes of the classes cestoda and nematoda in a wolf (Canis lupus) in Kabardino-Balkaria regione. Kabardiev S.Sh., Battirov A. $M$.

- Clinical case of detection of Eimeria brunetti broiler chickens in the Krasnoyarsk region. Frolova O. A., Afonyushkin V.N., Donkova N. V.

- The role of toxicosis in the adaption of ecosystems for anthropogenic pollution of the environment (at the example of toxicosis of water animals). Makrushin A.V.,Vasiliev A. S., Arshanitsa N. M., , Lyashenko O. A., ,Stekolnikov A. A., , Grebtsov M. R.

- Monizen forte for lambs parasitic diseases. Engasheva E. S., Kolesnikov V. I.

- The use of a composition of biostimulants for the increase in the quantitative and qualitative indicators of incubation. Lugovaya I.S.

- Dynamics of protein fractions of horse blood serum when dehelmintizing a drug from a group of macrocyclic lactons on the background of application of probiotics. Mullagalieva O.A., Zakrepina E.N., Voevodina Yu.A.

- Antimicrobial activity of enrofloxacin in vitro . Yurin D.V., Nevzorova V. V.-, Balbutskaya A.A., Belimova S.S. 
Международный вестник ветеринарии, № 2, 2020 2.

- Treatment of experimental salmonellosis in chickens with fluoroquinolone antimicrobials. Skvortsov V.N., Yurin D.V., Nevzorova V. V., Mazur A. D.

- New BA-12 disinfectant for disinfection soil foci of anthrax. A. A. Sultanov , Suchshikh V.Y., Kanatov B., Nyrlan Kjunior

- The effect of the drug "Hepaton" on the reaction of lipid peroxidation. V.S. Ponamarev, O.S. Popova

- The effect of the drug with hepatoprotective activity "Hepaton" on the peripheral blood parameters of laboratory animals. V. S. Ponomarev

- Use of sorbents in fish farming. Baryshev, V. A., D. U. Tashbaev, O. S. Popova

Zoohygiene, Sanitation, Feeding
Biochemistry, anatomy, physiology
- Application of ngs for evaluating the symbiotic microflora of the reindeer rumen in the russian Arctic. Ilyina L.A., Ph.D., Filippova V.A., Yildirim E.A., Dubrovin A.V., Dunyashev T.P.1, Sobolev D. V., Layshev K. A.

- Monitoring of aflatoxin b1 in forage of the republic of Tatarstan. Tanaseva S.A., Ermolaeva O.K., Matrosova L.E., Semenov E.I.

- Zoohygienic quality assessment of goats milk of various breeds. Tkachev A.V.

- The role of carbohydrate-vitamin-mineral concentrate in feeding goats. D.D. Khairullin, Sh.K. Shakirov, M.V. Antonov

- Study of indexes of the suckling productivity the cows of Ayrshire breed of tribal economy of the Leningrad area. Yu. V. Mukiy

- Influence of technological stress on the immunological reactivity of piglets. Kryachko O.V., Budnik A.O.

- Analysis of the influence of copper on carbohydrate metabolism in carp. Karpenko L. Yu., Polistovskaya P. A., Enukashvili A. I., Balykina A. B.

- Anatomical and topographical features of the area of pelvic bones of dorper sheep. Mamedkuliev A. K., Shchipakin M.V.

- Architectonics of the arterial system of the ruminant stomach of edilbaev sheep in age aspect. Melnikov S.I., Shchipakin M.V.

- Peculiarities of morphology of kidneys in broad-breasted turkey and Peking duck. Pervenetskaya M. V., Fomenko L. V.

- Dynamics of indicators of non-specific protection of holstein black-and-white breeds of cows depending on the month of pregnancy. Karpenko L.Y., Pogodaeva A.A., Bakhta A.A.

- Pathological changes with the enteropathy caused by difillobotriosis in dogs. Kamenov K.S., Shinkarenko A.N.

- The dynamics of cellular factors of the immune system of healthy minks, experimentally infected with eimeriidosis, under specific therapy. Kuznetsov Y. E., Kuznetsova N.V.

- Clinical trials of the drug in pigs with mycoplasmosis. Tokareva O.A., Tokarev A.N., Engashev S.V., Engasheva E.S., Musin A.R., Vasil'eva N.S.
108

8

2

6

7

\section{2}


Международный вестник ветеринарии, № 2, 2020 г.

Obstetrics,

Gynecology
- Measures aimed at prevention of cow's mastitis incidence. Batrakov A.Y., Plemyashov K.V., Videnin V.N., Yashin A.V.

- Search and development of a method of therapy for postpartum endometritis in cows. Pereryadkina S. P., Boldarev A.A., Kolesnikov P.V., Galchenko V. A

- Stimulation of reproductive function in first - born cows. Gamayunov V. M., Koltsov D. N., Onufriev V. A., Tselueva N. I. 